\title{
Human trafficking in Nepal: A rising concern for all
}

\author{
Joshi SK \\ Associate Professor, Department of Community Medicine, Kathmandu Medical College
}

$\mathrm{H}$ uman trafficking is the fastest growing, criminal industry in the world. But, relatively little is known about the issue of human trafficking and the effectiveness of programmes aimed at combating trafficking and rehabilitating victims/survivors.

Trafficking of Nepalese women and girls to Indian brothels was established in 1960. Even before that during the Rana rule in Nepal women required a special authorisation to go to India. About 50 percent of Nepal's female sex workers have previously worked in Mumbai and more than 200,000 Nepalese girls are involved in the Indian sex trade ${ }^{1}$. According to the working agencies in anti-trafficking activities in Nepal, there is increasing tendency in trafficking among middle class women who are being trafficked to Gulf countries under the veil of attractive jobs and handsome salaries. The magnitude of trafficking has increased over the years, but neither the extent not the real expansion has been verified. The illegal structure of trafficking, community vested interests, and lack of actual information/data and networking among stakeholders are the major constraints to preventive measures of trafficking. Disadvantaged groups in all spheres of Nepali society plus the one and half decade long severe political instability and internal conflict contribute to increasing vulnerability to trafficking. Many studies in the past revealed that the conflict induced inflows of women and girls to urban Nepal increased the commercial sexual exploitationand thus internal trafficking too.

Over the past few years, research has been a crucial component of anti-trafficking measures, but statistical data on trafficking victims remains widely varied. Figures range from 12,000 per annum as per an ILO report to over 20, 0000 Nepali girls being trafficked to Indian brothels as per Maiti Nepal ${ }^{2}$. UNICEF (1998) shows that more than $20 \%$ of the total persons involved in sex work in Nepal are under the age of 16 years, with some as young as 11. Similarly, an ILO report shows that 29 districts of Nepal have high occurrence of trafficking ${ }^{3}$, whereas, UNIFEM study ${ }^{4}$ identifies 39 districts as vulnerable compared to 26 identified by government of Nepal. However, NGOs working in these sectors claimed that 70 districts out of 75 are vulnerable in terms of human trafficking. These figures are based on trafficking cases reported in 2008.

Nepalese girls, trafficked and sold into prostitution in India, are abandoned when they become infected with HIV. Out of the 218 Nepalese girls rescued in February 1996 from a Bombay brothel, 60-70\% of them were HIV positive 5 . Due to their highly marginalized status, Female Sex Workers in Nepal have limited access to information about reproductive health and safe sex practices.

The following initiatives have been undertaken by the Government of Nepal at the legislative and policy levels toward anti trafficking intervention programmes:

- The National Legal Code (Muluki Ain), 1963, lays down as offence the separating of a minor below 16 years from the guardian or enticing the minor to "cross the border with the intent of trafficking or striking a deal in this regard". Article 3 prohibits the sale or purchase of any person.

- Under the Human Trafficking Control Act of 1986, transporting a person to a foreign country with the intention of selling and forcing a woman into prostitution are offences punishable with imprisonment for up to 20 years.

- The Legal Code, Part IV, Chapter 14 on rape, prohibits sexual exploitation. Assault and molestation of a girl child under the age of 16 , with or without her consent is a crime.

- In 1990, the Constitution of Nepal included a provision which provides for special laws to prohibit traffic in human beings, slavery, serfdom, or forced labour in any form and thus seeks to protect women and children by making trafficking punishable by law.

- Nepal Government has signed the SAARC Convention on Prevention and Combating Trafficking in Women and Children in 2002. This was a major step taken to combat women/girls trafficking in Nepal.

- A National Task Force on Trafficking has been set up with representatives from the Ministries of Home, Education, Health, Labour, as well as representatives 
from law enforcement NGO network, UNICEF and ILO.

The Ministry of Women and Social Welfare is mainly responsible to deal with the issue of trafficking of women and children for prostitution. It has formulated a National Plan of Action regarding the control and elimination of trafficking of women and children into the sex market. A transit home has been set up for the victims under this ministry. There is also a training centre for imparting skills. Similarly, a new Bill on trafficking is currently being drafted and discussed. It has been emphasized that the existing laws related to women shall be amended and legal and implementation provisions made for preventing traditional violence such as Witch hunt, Jhuma, Deuki and Badi. Nepal is signatory to a total 11 different international conventions related to women's rights out of 21 human rights till end of 2008 .

We do have effective policies that address trafficking for sexual and labour exploitation. But, inefficient government mechanism to implement national and international commitments hinders the prevention of trafficking. However, the recently developed political scenario and social transition have brought a few rays of hope in the improvement of situation by correcting the policies and adopting effective measures to control women/girls trafficking. There is a lack of institutionalized reporting system in human trafficking in the country. Variation in the available data from previous surveys/research create obstacle to mapping the trafficking situation and anti-trafficking activities. Thus, in order to determine priorities, reliable and uniform data on trafficked persons should be made available. Findings of the studies conducted by various agencies should be disseminated and the stakeholders be made aware of the actual facts in the country.

Inadequate qualified and experienced expertise in this field is another drawback to combat human trafficking in Nepal. Trafficked persons are abused physically, emotionally and mentally. Such experiences have long term effects on victim's health. These people need professional help and support to overcome the situation. Health care workers' role here is also very important $^{6}$. Ethical issues have to be associated with the research process in trafficking. Doing research on violence in persons in Nepal requires a lot of patience, devotion, compassion and commitment from the part of investigators. In cases of women's situation of absolute victimization, it is not only unethical for researcher to be unfriendly from their situation but it is also inhuman not to be compassionate. It is to deal with the researcher's compassion, consciousness and importantly ethics and loyalty toward research on this area $^{7}$. Without comprehensive, carefully documented research on trafficking, it is impossible to know whether women are experiencing more violence in some countries than in others, or whether they are reporting it more often. With research, advocates can better understand the obstacles and develop appropriate methods for combating them. Research can motivate the government and civil society to take action once the extent of a problem is proven.

Advocacy trainings help in systematic and effective lobbying in respect to the various aspects of trafficking as well as awareness arising in general. Therefore, it is important to improve research methods and techniques for gathering more reliable quantitative and qualitative data. Further research will also be required to collect data on trafficked persons and identify those vulnerable to trafficking, and to know the extent and magnitude of both internal and trans-boarder trafficking in changing scenario of Nepal. Similarly, it is essential to promote and provide preventive and curative health facilities and sensitisation education to combat against trafficking to the vulnerable communities/school child and long term follow up.

\section{References}

1. Sangroula Y. Trafficking of Girls and Women in Nepal: Building a community Surveillance System for Prevention. Kathmandu: Kathmandu School of Law (Kathmandu); 2001.

2. McGirk T. Nepal's Lost Daughters, 'India's soiled goods. Nepal/India News 1997 Jan 27.

3. Hardman R. Prince brings hope to Nepal's rescued sex slaves. London Telegraph 1998 Feb 9.

4. New ERA. A situation analysis of sex work and trafficking in Nepal. Kathmandu: New ERA/ UNICEF; 1998.

5. Wadhwa S. Nepal - Facts on Trafficking and Prostitution, Coalition Against Trafficking in Women. In: Fact book on Global Sexual Exploitation. Combating Human Trafficking in Asia: A resource Guide to International and regional Legal instrument, political commitments and recommendation practices. New York: Economic and social commission for Asia and Pacific, United Nations; 2003.

6. Joshi SK. Violence against women in Nepal: Role of health care workers. Kathmandu Univ Med J (KUMJ) 2009;7(26):89-90.

7. Joshi SK, Kharel J. Violence Against Women in Nepal - An Overview [Online]. 2008 May 22 [Cited 2010Apr 22]. Available from: http://www. thefreelibrary.com/Violence Against Women in Nepal -- An Overview-a01073875052. 